Bangladesh Journal of Anatomy January 2012, Vol. 10 No. 1 pp 17-19

\title{
Role of Vitamin E on Indomethacin Induced Low Epididymal Sperm Count in Long Evans Rats
}

\author{
Md. Jahangir Alam¹, Humaira Naushaba², Uttam Kumar Paul ${ }^{3}$, Tahmina Begum ${ }^{4}$, ABM Omar \\ Faruque $^{5}$, Sabiha Mahbub ${ }^{6}$
}

\begin{abstract}
Context: Indomethacin is the most commonly and widely used nonsteroidal antiinflammatory analgesic and antipyretic drug. Though it is effective in various diseases, indomethacin causes inhibition of spermatogenesis and reduces the epididymal sperm count leading to infertility. On the other hand, vitamin E enhances spermatogenesis and increases the epididymal sperm count. Therefore the present study was designed to observe the protective role of vitamin $E$ on indomethacin induced testicular damage.
\end{abstract}

Objective: To observe the effect of vitamin E on indomethacin induced low epididymal sperm count in Long Evans rats.

Study design: An experimental study.

Place and period of study: The study was carried out in the Department of Anatomy, Sir Salimullah Medical College, Dhaka, during the period of August, 2005 to June, 2006.

Materials and methods: Eightyfour mature Long Evans male rats were divided into four groups (I, II, III and IV). The rats of group I, II and III were treated with indomethacin at different doses and duration. Group IV rats were treated with indomethacin plus vitamin $E$ at different doses for 49 days. The epididymis of all the groups were collected after sacrificing the rats. Then the epididymal sperm were counted.

Results: There was significant reduction $(P<0.001)$ of epididymal sperm count when the rats were treated with indomethacin at low (2 mg/kg body weight/day) and high (10 mg/kg body weight/day) doses for 7,14 and 42 days, respectively. On the other hand, rats treated with indomethacin plus vitamin $E$ for 49 days showed significant increase in epididymal sperm count compared to other groups $(P<0.001)$.

Conclusion: It can be concluded from this study that vitamin $E$ has potential role in the prevention of the antispermatogenic effects of indomethacin.

Key words: Epididymis, Indomethacin, Vitamin E

\section{Introduction}

Indomethacin is the most commonly and widely used nonsteroidal antiinflammatory (NSAID), analgesic and antipyretic drug. It was first

1. Assistant Professor, Department of Anatomy, Sir Salimullah Medical College, Dhaka

2. Professor and Head, Department of Anatomy, Sir Salimullah Medical College, Dhaka

3. Assistant Professor, Department of Anatomy, Sir Salimullah Medical College, Dhaka

4. Lecturer, Department of Anatomy, Sir Salimullah Medical College, Dhaka

5. Associate Professor and Head, Department of Anatomy, Sappora Dental College, Dhaka

6. Associate Professor (c.c), Department of Anatomy, Shahab Uddin Medical College, Dhaka

Correspondence: Dr. Md. Jahangir Alam introduced in 1963 for the treatment of rheumatoid arthritis and related disorders ${ }^{1,2,3}$. Though it is an effective drug, toxic effect to testis and accessory sex organs have significantly restricted its use. Prolonged treatment with indomethacin caused a marked effect in altering the metabolism of the testis, epididymis and other accessory sex organs, and reduces fertility significantly by lowering the epididymal sperm count ${ }^{4}$.

On the other hand, vitamin $E$ is a fat soluble vitamin. It enhances spermatogenesis by inhibition of lipid peroxidation and lowers the incidence of abnormal sperm production and significantly increases the epididymal sperm count ${ }^{5,6}$. 
Therefore, the present study was designed to observe the protective role of vitamin $E$ on indomethacin induced low epididymal sperm count.

\section{Materials and Methods}

Eightyfour mature Long Evans rats of 2.5 to 3.5 months old, weighing 200300 gms were included in this study.

\section{Methods}

Eightyfour male rats were divided into four main groups (I, II, III and IV). These main groups were again divided into three subgroups 'a' (control), 'b' (indomethacin $2 \mathrm{mg} / \mathrm{kg}$ body weight/day) and ' $\mathrm{c}$ ' (indomethacin $10 \mathrm{mg} / \mathrm{kg}$ body weight/day). Each subgroup included 7 rats. Grouping of animals and their treatment were done on the basis of duration of treatment.

Rats of group I, II and III were treated by indomethacin at low and high doses for 7, 14 and 42 days, respectively. Group IV rats were treated with indomethacin at low $(2 \mathrm{mg} / \mathrm{kg}$ body weight/ day) and at high (10 $\mathrm{mg} / \mathrm{kg}$ body weight/day) dose plus vitamin $\mathrm{E}$ ( $100 \mathrm{mg} / \mathrm{kg}$ body weight/day) for 49 days.

Procedure for measuring epidymal sperm count: For determination of epididymal sperm count, the animals were sacrificed by cervical dislocation under ether anaesthesia ${ }^{7}$. After sacrifice, the abdomen of the rats were opened at autopsy and the right epididymis was taken out and was placed in glass dish with $2 \mathrm{ml}$ of $0.9 \% \mathrm{NaCl}$ and gently minced with a fine scissors. The extract was diluted in 1 in 20 with $0.9 \% \mathrm{NaCl}$ in a white blood cell (WBC) pipette. The counting chamber of improved Neubauer haemocytometry was filled with the diluted extract. The number of spermatozoa in 5 small squares as done in WBC (white blood cell) were counted. The total count was obtained by multiplying the number with one million. Two samples were counted from each epididymis within one hour of sacrifice and the mean value was taken ${ }^{9}$.

For statistical analysis, the data obtained from different groups of rats were analyzed and comparisons were made using unpaired Student's 't' test.

\section{Results}

There was significant reduction $(P<0.001)$ in epididymal sperm count when the rats were treated with indomethacin at low $(2 \mathrm{mg} / \mathrm{kg}$ body weight/ day) and high (10 mg/kg body weight/day) dose for 7,14 and 42 days respectively. On the other hand, rats treated with indomethacin plus vitamin $\mathrm{E}$ for 49 days showed significant increase $(P<0.001)$ in epididymal sperm count compared to control and other groups (Table I and Fig. 1).

Table I

Effect of indomethacin/indomethacin plus vitamin $E$ on epididymal sperm count of different groups of rats

\begin{tabular}{|c|c|c|}
\hline Groups & $\begin{array}{l}\text { Duration of } \\
\text { treatment } \\
\text { (in days) }\end{array}$ & $\begin{array}{c}\text { Epididymal sperm } \\
\text { count (in millions) } \\
\text { Mean } \pm S D\end{array}$ \\
\hline la & $\begin{array}{c}7 \\
(90.0105 .0)\end{array}$ & $88.14 \pm 5.553$ \\
\hline $\mathrm{lb}$ & $\begin{array}{c}7 \\
(75.085 .0)\end{array}$ & $80.29 \pm 4.15$ \\
\hline Ic & $\begin{array}{c}7 \\
(65.075 .0)\end{array}$ & $70.29 \pm 4.15$ \\
\hline Ila & $\begin{array}{c}14 \\
(100.0120 .0)\end{array}$ & $109.29 \pm 6.73$ \\
\hline $\mathrm{Ilb}$ & $\begin{array}{c}14 \\
(50.065 .0)\end{array}$ & $59.29 \pm 5.35$ \\
\hline IIc & $\begin{array}{c}14 \\
(40.055 .0)\end{array}$ & $47.14 \pm 4.88$ \\
\hline Illa & $\begin{array}{c}42 \\
(100.0120 .0)\end{array}$ & $109.29 \pm 6.73$ \\
\hline IIIb & $\begin{array}{c}42 \\
(75.085 .0)\end{array}$ & $78.86 \pm 3.98$ \\
\hline IIIC & $\begin{array}{c}42 \\
(25.040 .0)\end{array}$ & $32.50 \pm 5.24$ \\
\hline IVa & $\begin{array}{c}49 \\
(95.0110 .0)\end{array}$ & $105.00 \pm 5.77$ \\
\hline $\mathrm{IVb}$ & $\begin{array}{c}49 \\
(100.0115 .0)\end{array}$ & $107.86 \pm 4.88$ \\
\hline IVc & $\begin{array}{c}49 \\
(45.0 \\
\end{array}$ & $\begin{array}{c}52.86 \pm 7.56 \\
.0665 .0) \\
\end{array}$ \\
\hline
\end{tabular}

\begin{tabular}{l|l} 
la & \\
Ila & Control, $2 \mathrm{ml}$ distilled water/day \\
Illa & \\
IVa & \\
Ib & \\
Ilb & Indomethacin $2 \mathrm{mg} / \mathrm{kg}$ body weight/day \\
IIlb & \\
IC & \\
Ilc & Indomethacin $10 \mathrm{mg} / \mathrm{kg}$ body weight/day \\
IIlc & Indomethacin $2 \mathrm{mg} / \mathrm{kg}$ body weight plus \\
IVb & vitamin E $100 \mathrm{mg} / \mathrm{kg}$ body weight/day \\
IVc & $\begin{array}{l}\text { Indomethacin } 10 \mathrm{mg} / \mathrm{kg} \text { body weight plus } \\
\text { vitamin E } 100 \mathrm{mg} / \mathrm{kg} \text { body weight/day }\end{array}$
\end{tabular}




\begin{tabular}{|c|c|}
\hline Groups & $P$ value \\
\hline la vs Ib & $<0.001^{* \star *}$ \\
\hline la vs Ic & $<0.001^{* * *}$ \\
\hline Ib vs Ic & $<0.001^{* * *}$ \\
\hline Ila vs Ilb & $<0.001^{* * *}$ \\
\hline Ila vs IIc & $<0.001^{* * *}$ \\
\hline Ilb vs Ilc & $<0.001^{* * *}$ \\
\hline IIla vs IIlb & $<0.001^{* * *}$ \\
\hline IIla vs IIIC & $<0.001^{* * *}$ \\
\hline IIlb vs IIIc & $<0.001^{* * *}$ \\
\hline IVa vs IVb & $>0.10^{\mathrm{ns}}$ \\
\hline IVa vs IVc & $<0.001^{* * *}$ \\
\hline IVb vs IVc & $<0.001^{* * *}$ \\
\hline IIlb vs IVb & $<0.001^{* * *}$ \\
\hline Illc vs IVc & $<0.001^{* \star *}$ \\
\hline
\end{tabular}

Figures in parentheses indicate range. Comparison between groups done by Unpaired Student's 't' test.

\section{Discussion}

The reduction in the epididymal sperm count were highly significant $(P<0.001)$ in the rats treated with indomethacin at low and high doses for longer duration (14 and 42 days).

Similar findings were also observed by Balasubramanian et al. ${ }^{7}$, Kumar and Chinoy ${ }^{6}$ and Ara $^{10}$.

The epididymal sperm count increased markedly $(P<0.001)$ in vitamin $E$ treated rats in comparison to control group and in indomethacin treated group of rats. This result is similar to the results observed by Cooper and Carpenter ${ }^{8}$, Mishra and Acharya ${ }^{5}$. The increase in epididymal sperm count in group IV (vitamin $E$ treated) might be due to inhibition of lipid peroxidation, which enhances spermatogenesis and lowers the incidence of abnormal sperm production.

\section{References}

1. Robert LJ, Morrow JD. Analgesic antipyretics and antiinflammatory agents and drugs employed in the treatment of gout. In: Limbrid LE, Hardman JG, editors. Goodman and Gilman's: the pharmacological basis of therapeutics. 16th ed. New York: MacGraw Hill Companies, 2001: 687-731.

2. Guyton AC, Hall JE. Textbook of medical physiology. 10th ed. Philadelphia: WB Saunders Company, 2002: 916-28.

3. Ganong WF. Review of medical physiology. 21st ed. New York: MacGraw Hill Companies, 2003: 428-37.

4. Loscher W, Blazaki D. Effect of nonsteroidal antiinflammatory drugs on fertility of male rats. J Reprod Fert 1986; 76:65-73.

5. Mishra M, Acharya VR. Protective effect of vitamin $\mathrm{E}$ on spermatogenesis in lead treated Swiss mice. Med J Biol Trace Elem 2004; 18;173 78.

6. Kumar RA, Chinoy NJ. Effects of acetyl salicylic acid on reproductive organs of adolescent male rats. J Endocrin Expl 1988; 22:187-95.

7. Balasubramanian A, Manimekalai S, Guna Singh A, Rama Krishnan S. Short and long term effect of aspirin on testes of albino rats. Indian J Expl Biol 1980; 18:1408-10.

8. Cooper DR, Carpenter MP. Sertoli cell prostaglandin synthesis: effects of (follitropin) differentiation and dietary vitamin E. Biochem J 1987; 241:847-55.

9. Banu MLA. Protection from cyclophosphamide induced damage of spermatogenesis in the rat by androgen [thesis]. Dhaka: University of Dhaka, 1997.

10. Ara S. Histomorphological changes in tests induced by aspirin and its prevention by prostaglandins in rat [thesis]. Dhaka: University of Dhaka, 1992. 